\title{
New onset left bundle branch block: keep calm!
}

\author{
Pasquale Crea ${ }^{a}$, Antonio Bracco ${ }^{a}$, Teresa Crea ${ }^{b}$ \\ ${ }^{a}$ Cardiology, Department of Clinical and Experimental Medicine, University of Messina, Italy \\ ${ }^{b}$ Internal Medicine, Department of Clinical and Experimental Medicine, University of Messina, Italy
}

\section{ARTICLE INFO}

Article history:

Submitted: 11. 11. 2018

Accepted: 9. 2. 2019

Available online: 30. 9. 20019

Klíčová slova:

Blokáda levého Tawarova raménka

Hyperkalemie

Infarkt myokardu

Selhání ledvin

STEMI

Keywords:

Hyperkalemia

Kidney failure

Left bundle branch block

Myocardial infarction

STEMI

\section{SOUHRN}

Nově vzniklá blokáda levého Tawarova raménka (left bundle branch block, LBBB) je rovnocenná STEMI a podle současných doporučených postupů je třeba ji řešit primární angioplastikou. Vznik LBBB může být, kromě infarktu myokardu, důsledkem několika jiných postižení, např. hyperkalemie. Pro léčbu, zvláště v naléhavých situacích, je naprosto zásadní rozpoznat jinou takovou možnou prríčinu, aby se předešlo léčbě, která by byla zbytečná nebo, co by bylo ještě horší, pacientovi by uškodila. Správnou diagnózu často umožnilo stanovit klinické vyšetření a pozorná kontrola elektrokardiogramu.

(C) 2019, ČKS

\section{ABSTRACT}

New onset LBBB represents a STEMI equivalent and, according to the current guidelines, this qualifies for primary angioplasty. However, several conditions could provoke new onset LBBB such as hyperkalemia, hypercalcemia etc. Differential diagnosis is fundamental, especially in emergency condition, in order to avoid unnecessary or harmful treatment. Clinical evaluation and careful analysis of ECG often permitted the correct diagnosis.

\section{Introduction}

For ST segment elevation myocardial infarction (STEMI) patients, access to percutaneous coronary intervention is critical. Door-to-balloon time is used as a performance measure to assess the quality of care that STEMI patients are receiving. Thus, the best practice for STEMI patients involves early diagnosis and immediate activation of the cardiac catheterization laboratory. STEMI equivalents are those patients who do not present with this classical ECG changes but have acutely occluded coronary artery. They are often associated with poorer outcome and worse prognosis. New onset LBBB represents a STEMI equivalent and, according to the current guidelines ${ }^{1}$, this qualifies for primary angioplasty. However, new onset left bundle branch block (LBBB) is not specific for acute myocardial infarction.

\section{Case presentation}

A 69-year-old man was admitted to the emergency department with profound asthenia. In the last three days, he suffered from mild and diffuse abdominal pain with diarrhea. In his past medical history:

- Hypertension, diabetes mellitus and dyslipidemia;

- Paroxysmal atrial fibrillation;

- Twenty years ago, inferior myocardial infarction followed by coronary artery bypass surgery for trivascular coronary obstruction;

- About ten years ago, femorofemoral bypass for right common iliac artery occlusive disease;

- Three months ago, intestinal infarction treated with resection, direct anastomosis and protective ileostomy.

His medications included betablocker, ACE inhibitor in combination with low dose thiazide diuretic, vitamin $\mathrm{K}$ antagonist oral anticoagulant, metformin, statin.

On admission blood pressure was $90 / 60 \mathrm{~mm} \mathrm{Hg}$. The patient was alert and oriented. Physical examination showed dry mouth and skin without peripheral edema. Cardiopulmonary examination showed bilateral air entry without any adventitious sounds and normal heart sounds without murmurs, gallop or rub. The ECG showed (Fig. 1) sinus rhythm, first degree AV block and left bundle branch 


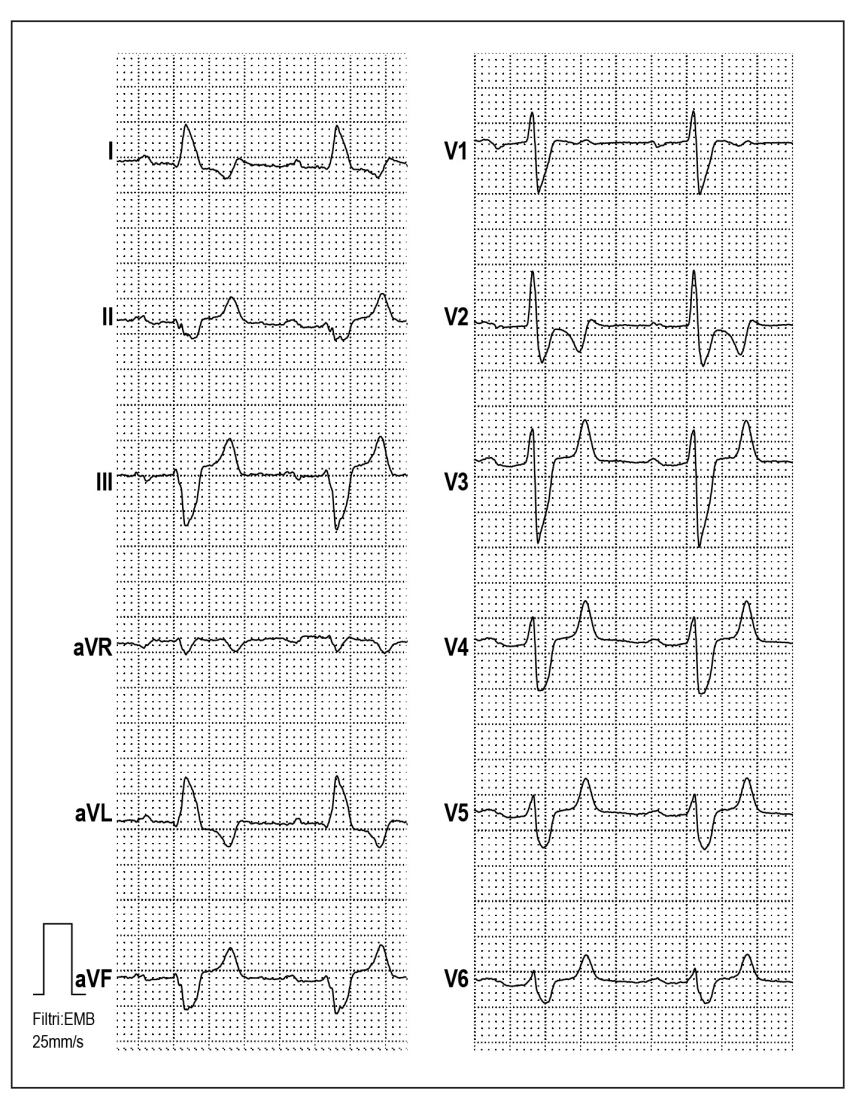

Fig. 1 - ECG on admission

block. A previous ECGs (performed three months ago, during his previous hospitalization for intestinal infarction) were avalaible and showed only left anterior fascicular block with signs of inferior necrosis.

Question: Did new onset LBBB suggest an acute myocardial infarction? Should the patient have had to undergo coronary angiography?

A careful analysis of ECG on admission showed a significative narrowing down of the base of the $T$ waves (with a duration about 100-120 ms), resulting peaked. This behavior suggested a possible hyperkalemia. First degree AV block and widening of QRS complexes, in respect of previous ECG, were accordant with this hypothesis. Moreover LBBB resulted atypical due to slow rise of initial portion of the QRS, prominent $R$ waves in leads $V_{1}$ to $V_{3^{\prime}}$ little $q$ waves in I and aVL, $r S$ complex with large $s$ wave in $V_{6}$. Sgarbossa criteria, for diagnosis of acute ischemia in the presence of LBBB, were negative. An echocardiogram was quickly performed, demonstrating a mild left ventricular dysfunction (EF 45\%) with inferior wall akinesia, fully justified by previous infarction. Arterial blood gas test showed these data, suggesting metabolic acidosis: $\mathrm{pH} 7.29, \mathrm{pCO}_{2} 36.8 \mathrm{mmHg}, \mathrm{PO}_{2} 88 \mathrm{mmHg}, \mathrm{HCO}^{-} 14$ $\mathrm{mmol} / \mathrm{L}$. Blood potassium level of $8.3 \mathrm{mmol} / \mathrm{L}$ confirmed suspicion of hyperkalemia. Serum creatinine level $5.5 \mathrm{mg} /$ dl (normal value 0.5-1.2) and increased azotemia $125 \mathrm{mg} /$ dl (n.v. 10-50) denounced acute kidney injury. Biochemical markers of myocardial necrosis resulted within normal range.

Thus, clinical and laboratory data excluded acute coronary syndrome. Intravenously calcium gluconate was

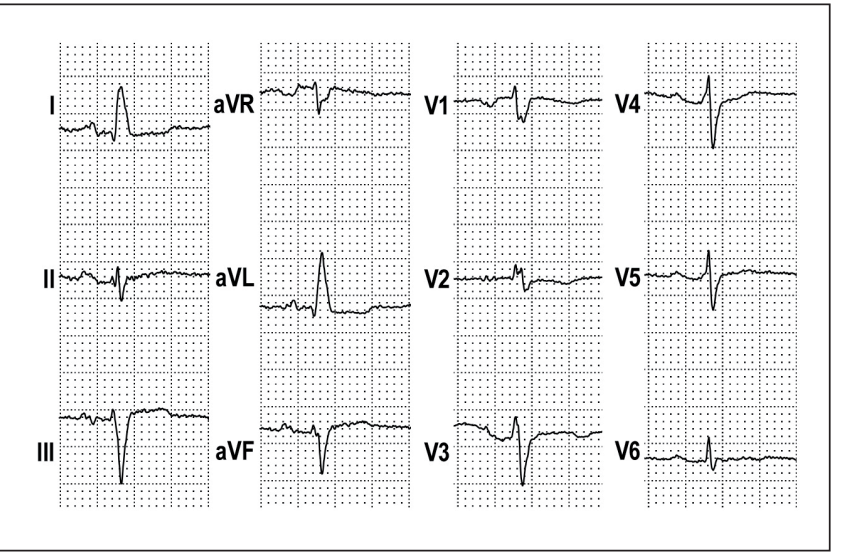

Fig. 2 - ECG after normalization of kalemia

promptly administered in order to reduce potassium level. The patient underwent bicarbonate dialysis treatment, followed by gradual reduction of creatinine and azotemia levels and pH normalization. ECG (Fig. 2) after hemodialysis showed a resolution of the left bundle branch pattern. A repeat serum chemistry after hemodialysis showed improvement in serum potassium level to $4.8 \mathrm{mEq} / \mathrm{L}$. On discharge, renal scintigraphy showed reduction of glomerular filtration rate about $47.8 \mathrm{ml} / \mathrm{min}$, denouncing moderate chronic kidney failure. ACE-inhibitor was stopped.

\section{Discussion}

LBBB is generally associated with a poorer prognosis in comparison to normal intraventricular conduction, but also in comparison to right bundle branch block which is generally considered to be benign in the absence of an underlying cardiac disorder, like congenital heart disease. LBBB may occur in asymptomatic individuals, patients with extensive myocardial infarction, and in those with heart failure, especially in dilated, non-ischemic cardiomyopathies. In some patients, LBBB (sometimes rate dependent) may be the first manifestation of heart disease whereas the clinical presentation of a dilated cardiomyopathy develops only some years later. According to the last guidelines, patients with a clinical suspicion of ongoing myocardial ischaemia and LBBB should be managed as STEMI patients, regardless of whether the LBBB is previously known. ${ }^{2}$ However, a new LBBB does not predict a myocardial infarction per se. ${ }^{3}$ Sgarbossa criteria could be helpful in order to assess ischemia in the presence of LBBB. ${ }^{4}$ The Sgarbossa criteria consists of ST-segment elevation of $1 \mathrm{~mm}$ or more concordant with the QRS complex in any lead (score of 5), ST-segment depression of $1 \mathrm{~mm}$ or more in lead $\mathrm{V}_{1}, \mathrm{~V}_{2}$ or $\mathrm{V}_{3}$ (score of 3) and STsegment elevation of $5 \mathrm{~mm}$ or more discordant with the QRS complex in any lead (score of 2). A total score of $\geq$ 3 is reported to have a specificity of $90 \%$ for diagnosing myocardial infarction.

Several conditions could provoke new onset LBBB such as hyperkalemia, hypercalcemia, ${ }^{5}$ pharmacological effect (especially with class IC antiarrhythmic drugs), intermit- 
tent phase 3 (tachycardia-dependent) branch block, myocarditis, dilated cardiomyopathy. Differential diagnosis is fundamental, especially in emergency condition, in order to avoid unnecessary or harmful treatment.

Hyperkalemia is a medical emergency and is considered severe, with high mortality rate, when the serum potassium level is $8.0 \mathrm{mEq} / \mathrm{L}$ or greater. The most common disorders associated with severe hyperkalemia include renal failure and critical illness such as sepsis and multisystem organ failure. Angiotensin-converting enzyme inhibitor, angiotensin II receptor blocker, NSAID and aldosterone antagonist are common medications known to contribute to hyperkalemia.

Tall and peaked $T$ waves are the most readily recognizable signs of hyperkalemia. In particular. narrowing down of the base of the T waves is important for diagnosis. Severe hyperkalemia can result in fascicular blocks and bundle branch blocks, due to depressed intraventricular conduction. It is worth noting that in hyperkalemia the conduction delay persists throughout the QRS complex and not just in the terminal portions, as seen in bundle branch block. In worst cases, the T waves broad and fuse with widened QRS complexes ("sine-wave appearance"). ${ }^{6}$ Rarely severe hyperkalemia provokes ST segment elevation, perfectly mimicking acute myocardial infarction. In this case differential diagnosis is really difficult by ECG. ST abnormalities are most frequently seen in leads $V_{1}$ and $V_{2}$ and, in some cases, resemble type 1 Brugada pattern.?

In patients with severe hyperkalemia, treatment includes i.v. calcium to ameliorate cardiac toxicity, IV glucose and insulin infusion to enhance potassium uptake by cells. Sodium bicarbonate infusion should be administered in order to correct metabolic acidosis. Emergency dialysis is recommended for patients unresponsive to more conservative measures or with severe renal failure. ${ }^{8}$

In our case, first ECG showed new onset LBBB, together with atypical symptoms. His medical history, consistent of multiple cardiovascular risk factors, triple CABG and peripheral vascular disease, induced suspicions of acute myocardial infarction. Clinical evaluation and careful analysis of ECG permitted the right diagnosis of acute kidney failure with severe hyperkalemia. Urgent coronary angiogram could have been harmful, due to use of iodine contrast in the setting of renal failure and metabolic acidosis.

\section{Conflict of interest}

None of the authors has any conflict of interest.

\section{Ethical statement}

Authors state that the research was conducted according to ethical standards.

\section{Informed consent}

The patient was asked to consider allowing Dr. Pasquale Crea to use his medical records to write a case report. The case report has been fully explained to the patient and all questions have been answered. We explained to the patient the objective of this manuscript, shared information experienced by one patient during his clinical care that may be useful for other physicians and members of a healthcare team, and may be published in Cor et Vasa Journal for others to read. The patient authorized access to his personal health information and he has agreed to participate in this case report.

\section{References}

1. Ibanez B, James S, Agewall S, et al. ESC Scientific Document Group. 2017 ESC Guidelines for the management of acute myocardial infarction in patients presenting with ST-segment elevation: The Task Force for the management of acute myocardial infarction in patients presenting with ST-segment elevation of the European Society of Cardiology (ESC). Eur Heart J 2018;39:119-177.

2. O'Gara PT, Kushner FG, Ascheim DD, et al. American College of Emergency Physicians; Society for Cardiovascular Angiography and Interventions. 2013 ACCF/AHA guideline for the management of ST-elevation myocardial infarction: a report of the American College of Cardiology Foundation/American Heart Association Task Force on Practice Guidelines. J Am Coll Cardiol 2013;61:e78-e140.

3. Jain $\mathrm{S}$, Ting $H T$, Bell M, et al. Utility of left bundle branch block as a diagnostic criterion for acute myocardial infarction. Am J Cardiol 2011;107:1111-1116.

4. Sgarbossa EB. Value of the ECG in suspected acute myocardial infarction with left bundle branch block. J Electrocardiol 2000;33(Suppl):87-92.

5. Cheng YT, Su CS, Chang WC, et al. Hypercalcemia-Induced New Onset Left Bundle Branch Block Mimicking Acute Myocardial Infarction in a Patient with Primary Hyperparathyroidism. Acta Cardiol Sin 2013;29:188-191.

6. Mattu A, Brady WJ, Robinson DA. Electrocardiographic manifestations of hyperkalemia. Am J Emerg Med 2000;18: 721-729.

7. Littmann L, Monroe MH, Taylor L III, Brearley WD. The hyperkalemic Brugada sign. J Electrocardiol 2007;40:53-59.

8. Ahee $P$, Crowe AV The management of hyperkalaemia in the emergency department. J Accid Emerg Med 2000;17:188-191. 